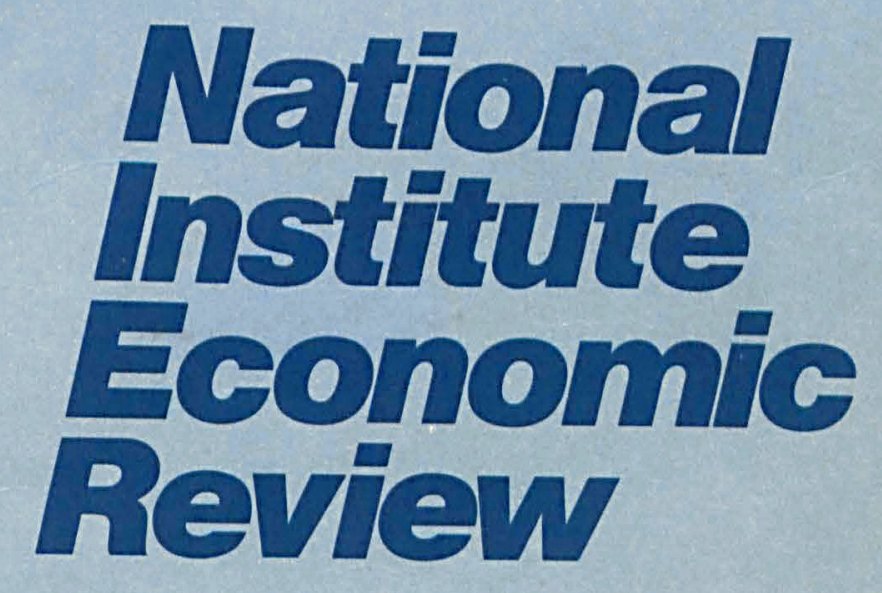




\section{RECENT SPECIAL ARTICLES AND NOTES}

1982

Nov. No. 102 The development of the EMS

(S. A. B. Page)

Bank lending to industrial and commercial companies in three models of the UK economy

(K. Cuthbertson and N. Foster)

1983

Feb. No. 103 Public sector borrowing

(A. J. C. Britton)

Income in work and when unemployed: some problems in calculating replacement ratios (C. Trinder)

Re-estimation of the National Institute model (Simon Brooks and Brian Henry)

May No. 104 World economy forecast post-mortems: $1972-82$ (K. M. Barker)

The economic effects of North Sea oil

(F. J. Atkinson, S. J. Brooks and S. G. F. Hall)

Comparative British and American productivity in retailing

(A. D. Smith and D. M. W. N. Hitchens)

Aug. No. 105 The assessment of the National Institute's forecasts of GDP, 1959-82

(D. Savage)

Policy trade-ofts in the NIESR model: exercises using optimal control

(S. Brooks, B. Henry, E. Karakitsos)

Some practical aspects of human capital investment: training standards in five occupations in Britain and Germany

(S. J. Prais and K. Wagner)

Nov. No. 106 The diffusion of mature technologies

(G. F. Ray)

The analysis of personal taxation and social (A. B. Atkinson, M. A. King and $H$. Sutherland)
1984

Feb. No. 107 The National Institute's forecasts of inflation, 1964-82

Changes in industrial structure

(George F. Ray)

The three measures of GDP

(Andrew Britton and David Savage)

Uncertainty, forecasting and budget changes

(A. J. C. Britton)

Public and private sector pay: a partly disaggregated study

(N. Foster, S. G. B. Henry and C. Trinder)

May No. 108 The growth of government expenditure (M. S. Levitt)

The roles of output expectations and liquidity in explaining recent productivity movements (S. Wren-Lewis)

The effects of economic policy: 1979-82

(M. J. Artis, R. Bladen-Hovell, E. Karakitsos and B. Dwolatzky)

Aug. No. 109 Confidence intervals

(S. G. Hall)

Fiscal policy and interest rates (Jane Darby)

Protectionism and European trade in manufactures

(Ann D. Morgan)

Full employment as a policy objective:

On the measurement of employment and unemployment

(David Metcalf)

Government, unions and stagflation in the UK

(Marcus Miller)

Is there an external constraint?

(John Williamson)

Nov. No. 110 Some aspects of labour markets in Britain and the United States

Industrial labour costs, 1971-1983

(G. F. Ray)

Macroeconomic policy in France and Britain (Kate Barker, Andrew Britton and Robin Major)

Economic recovery in the 1930s:

The sources of recovery in UK in the 1930 s

(G. D. N. Worswick)

Employment and real wages in the inter-war period

(N. H. Dimsdale)

Commodity Prices: the UNCTAD index

(G. F. Ray)

Annual subscriptions $£ 30.00$ (home) and $£ 40.00$ (abroad) and single issues for 1984 ( $£ 8.50$, home and $£ 12.00$, abroad) may be ordered from: The National Institute Economic Review, 2 Dean Trench Street, Smith Square, London SW1P $3 H E$. Students' subscriptions $£ 12.00$ a year on application to the Secretary of the Institute. Subscription prices include ordinary postage: for cost of airmail to countries outside Europe please apply to the above address.

Back numbers, up to and including no. 106, should be ordered from: Wm Dawson \& Sons Ltd, Cannon House, Park Farm Road, Folkestone, Kent. Nos. $1,3,5,6,10-12,14,16-19,26,32-4,39,43,46,55,68$ and 70 are out of stock in their original form, but reprints or photocopies are obtainable from the same address.

Microfilmed copies of back numbers are available from Microform Ltd, East Ardsley, Wakefield, West Yorkshire, WF3 2 AT. 


\title{
THE NATIONAL INSTITUTE OF ECONOMIC AND SOCIAL RESEARCH
}

This Review is intended to be of service to those, in business and elsewhere, who need to take a view of the general economic situation and prospects. The workings of the economy are not fully understood; and even if they were economic prediction would remain hazardous because of the impact of political events and technological developments. Nevertheless the Institute believes that a group of economists, presenting a comprehensive account of current economic developments and a coherent view of likely trends, can perform a useful service.

\section{Acknowledgements}

The Review was launched with the aid of a five-year grant from the Ford Foundation. Since 1966 the Economic and Social Research Council has made grants towards the cost of research and editorial work for the Review. The Institute gratefully acknowledges these grants and also the contributions from British companies and banks for support of the Institute's research. Subscriptions to the Review cover the cost of printing and distribution only.

The Institute is also grateful to many people in industry for giving the authors the benefit of their knowledge and experience, and to officials in Government departments who have assisted with advice in the interpretation of official statistics.

\section{Authorship}

The general articles in this Review are the joint work of members of the research staff, under the general supervision of the Editorial Board. When the contents are unsigned, the views expressed are the responsibility of the Editorial Board.

Most issues of the Review also include a number of signed articles in which the views expressed are the responsibility of the authors.

\section{EDITORIAL BOARD}
A. J. C. Britton
K. Cuthbertson
S. G. B. Henry
G. F. Ray
D. Savage (Editor)
Mrs K. Jones
S. Wren-Lewis
R. L. Major

Editorial assistant: Miss B. Yearsley

OTHER RESEARCH STAFF
Miss K. Barker
Mrs A. E. Cowen
G. F. Kennally
C. Trinder
S. G. F. Hall
C. B. Johns

ASSISTANT STAFF

\author{
Computing officer: H. Feisal \\ Statistical officers: Mrs J. E. Dare Mrs D. Swan Mrs P. Watts \\ Senior research assistant: Mrs S. Adler \\ Research assistants: R. Biswas M. Wall \\ Statistical assistant: Miss P. Dewes \\ Secretarial staff: Mrs R. Charlton Mrs A. Wright \\ Circulation office: Miss A. L. Stewart Miss Y. P. Mutch
}

